\title{
'Made in Japan' policy jettisoned in space
}

Tokyo. In a departure from its past policy, Japan's National Space Development Agency (NASDA) will import some components, rather than using only Japanese technology, for a planned upgrade of its $\mathrm{H}$ II launcher to make the rocket cheaper and better able to compete in the satellite launch market.

NASDA’s plan to spend $¥ 65$ billion (US\$0.7 billion) over the next five years on developing the upgrade was approved last week by the Space Activities Commission, Japan's principal government body for setting space policy.

At the end of this month, the Science and Technology Agency, which oversees NASDA, will request a budget of $¥ 2$ billion for fiscal year 1996 (which begins in April) to begin development of the upgraded H-II. Such budget requests are very seldom rejected, although the amount may be reduced slightly in negotiations with the Finance Ministry.

The upgrade will be able to place three to four tonnes of payload in geostationary orbit, compared with two tonnes for the current H-II.

Extra lift would be provided by using a liquid fuel LE-7 as a booster - an advanced liquid fuel engine used in the first stage of the current $\mathrm{H}-\mathrm{II}$ - in addition to the existing two solid fuel boosters. One or two LE-7 boosters would be added depending on the payload. The version with two LE-7 boosters would be used to launch the planned unmanned space shuttle HOPE.

The decision to import components of the launchers marks a shift in NASDA policy - one goal of the ten-year pro-

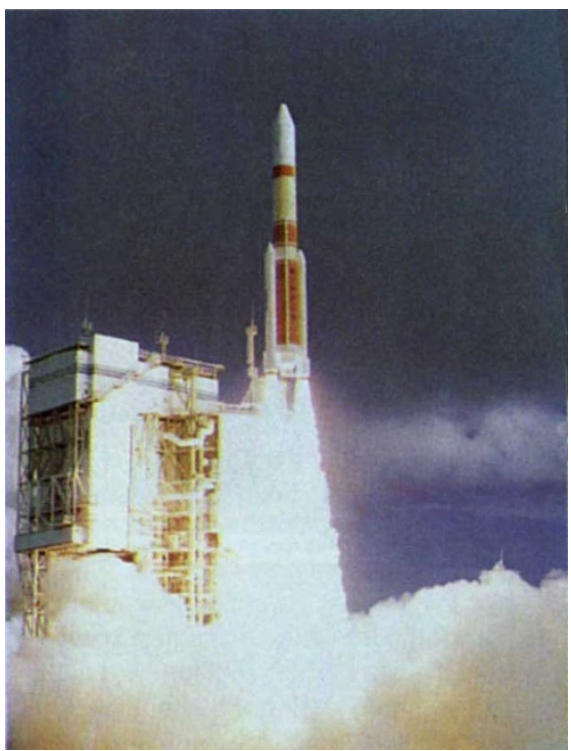

Japan's H-II launcher upgrade will be cheaper, more powerful - and part forelgn.

gramme to develop the current H-II, which NASDA began in 1984, was to end dependence on US technology by building an allJapanese launcher. The agency has not decided which components to import, according to one NASDA official, who says

\section{Very Large Quake shakes telescope}

Munich. A powerful earthquake earlier this month violently shook Mount Paranal, the site in the north Chilean desert of the Very Large Telescope (VLT).

The VLT, which is being built by the European Southern Observatory (ESO), will be the world's largest telescope when it is completed around the end of the century.

But the 8-magnitude earthquake seems to have caused little damage to the enclosure of the first telescope, which is scheduled to be installed next year, according to Massimo Terenghi, project manager of the VLT.

The telescope has been designed to withstand earthquakes of at least 8.5 -magnitude.

"The schedule for first light should not be affected", he says, although damage to the shock-absorbing columns will require several weeks to repair.

Since construction began early last year, the building of the VLT has been beset with problems arising from claims by a Chilean family to ownership of the site.

Legal action stopped work for three weeks in spring last year, but ESO has ignored subsequent embargoes claiming that it has immunity from local law (see Nature 373, 551; 1995).

The earthquake comes less than two months after the government stepped in and resolved the issue of ownership in ESO's favour. No casualties were reported at the Mount Paranal site, although three deaths were reported in Antofagasta, the nearest town, which lies $130 \mathrm{~km}$ to the south.

According to seismologists, an earthquake of similar intensity can be expected less than once a century in the area.

"Maybe it is good to have happened now, when we have only started the building of the enclosure for the first [of four] telescopes," says Terenghi.

It shows that the engineering design can withstand severe shocks, he says. ESO has offered 25 million(US\$65,000) to assist with reconstruction around Antofagasta, where hundreds of houses were destroyed, says ESO spokesman Roderigo di Castro, "to express its solidarity with the local community". that the matter is "still under study".

At the start of the H-II project, NASDA was confident that the $\mathrm{H}$-II could compete with other launchers in the commercial satellite launch market.

But the yen has since tripled in value against the dollar, and the cost of an H-II launch - around $¥ 19$ billion (US\$204 million) - is around double that of one using Europe's Ariane IV or the United States' Atlas and Delta.

Rocket Systems Corporation, the company created by a consortium of Japanese aerospace companies in 1990 to sell commercial H-II launches, has yet to win a single order.

But while NASDA has set itself the ambitious goal of reducing the cost of a launch by more than half - by using mass production in addition to importing cheaper components - one official from another launcher organization says he is sceptical that such savings can be achieved unless Japan can greatly increase the frequency of launches.

Indeed, NASDA can launch only within two short launch windows annually, in winter and summer, under an agreement with tuna fishermen near its launch centre on Tanegashima island off the coast of Japan's southern island of Kyushu.

Moreover, the government launches only one or two satellites a year and is unlikely to increase this frequency given its budgetary constraints. David Swinbanks

\section{Japanese science agency loses iron lady}

Tokyo. Japan's Science and Technology Agency (STA) last week lost its outspoken and popular leader, Makiko Tanaka, in a cabinet reshuffle.

Tanaka, who is a member of the Liberal Democratic Party (LDP), is renowned for her blunt and straightforward style, which has made her a favourite with the media, and led to STA's public prominence. Her father, the late Kakue Tanaka, was a former prime minister who resigned in the mid-1970s over a scandal about the purchase of Lockheed Tristar aircraft.

Selection of LDP members in the new cabinet was strongly influenced by Yohei Kono, the deputy prime minister who is seeking re-election as head of the LDP and Tanaka's successor, Yasuoki Urano is a soft-spoken consensus builder.

Tanaka's fame peaked earlier this year when she forced the dismissal of an STA officials who had opposed her wish to make public the names of semigovernment research and development corporations identified as needing reform.

David Swinbanks 